was demonstrated, and the fact that vitamin $\mathrm{D}$ is not active in vitro, but that it must be given to the animal at a definite interval before the gut is removed for in vitro study. These results then led others to a search for the events which occurred during this time interval, giving rise to the work on the calcium binding proteins and the metabolic transformations of vitamin $D$ to its most active hormonal form, 1, 25-dihydroxy vitamin $\mathrm{D}$.

Coincident with the advances in the knowledge of the metabolism and functions of vitamin D and interrelation with parathyroid hormone was the clinical development of methods for keeping alive patients with progressive renal disease by hemodialysis and kidney transplantation. These patients present serious problems of calcium and phosphate metabolism which can better be understood in the light of the new knowledge of vitamin $\mathrm{D}$ metabolism, particularly that the active metabolite, 1, 25-dihydroxy vitamin $D$, is formed in the kidney. Here again, one may well be impressed by our inability to predict the clinical applications of research done primarily to understand mechanisms.

Throughout all these research efforts, until 1969, our own intellectual curiosity was constantly stimulated and challenged by the person who was responsible for our coming to Hopkins, Dr. Edwards A. Park. How fortunate we were to have arrived at the Harriet Lane at the time of Dr. Park's retirement as Chairman of the Pediatrics Department and be able to share his unabated and boundless enthusiasm for scientific investigation, particularly regarding vitamin $D$ research and the mysteries of the calcification process. We shared not only his tremendous knowledge in this area, but were also the beneficiaries of his wide erudition: his love and interest in the classics, poetry, history, nature, but most of all we were the beneficiaries of his friendship and affection. Often, after we had been together, whether in the laboratory or at Dr. Park's home, we would receive a note which in effect continued the conversation. We cherish a large collection of such notes and letters. I quote from one written in 1958:

Dear Harold:

Here is what I promised to send. . .

and then Dr. Park quotes from a letter written by Benjamin Franklin to Dr. Joseph Priestley in 1780.

The rapid progress true science now makes, occasions my regretting sometimes that I was born so soon. It is impossible to imagine the heights to which may be carried, in a thousand years, the power of man over matter. . . .

$\mathrm{O}$, that moral science were in as fair a way to improvement that men would cease to be wolves to one another and that human beings would at length learn what they now improperly call humanity!

and in the postscript of this same letter from Dr. Park

P.S. The birds, the name of which I could not recall, which are localized on an island off the Gaspé peninsula are gannets.

The last letter we received just $5 \mathrm{wk}$ before his death, was a request for a reference to the work going on in the laboratory of Professor Hector DeLuca at the University of Wisconsin on the metabolic transformations of vitamin $\mathrm{D}$ to its hormonal form. In his interest and thinking Dr. Park remained at the forefront of the vitamin $\mathrm{D}$ field to the very end!

We take this occasion to thank the many talented associates who were part of our research. They added immeasurably to the pleasure as well as the progress of our work.

Over the many years of our investigative efforts our rewards have been the joy, excitement, and intellectual gratification which we have experienced in exploring new ideas. Now this Society adds a new dimension in considering our efforts of value in the "promotion of health in childhood." We are deeply grateful for this honor you have bestowed upon us. We thank you most sincerely.

\title{
Identification of the Major 4-Methylumbelliferyl p-Guanidinobenzoate-Hydrolyzing Plasma Protein in Cystic Fibrosis: Implication for Intrauterine and Heterozygote Detection
}

\author{
BRUCE R. BRANCHINI, ${ }^{(39)}$ GINO M. SALITURO, AND BERYL J. ROSENSTEIN \\ Biomedical Research Institute, The University of Wisconsin-Parkside, Kenosha, Wisconsin; Department of \\ Chemistry, The Johns Hopkins University, Baltimore, Maryland; and Department of Pediatrics, The Johns \\ Hopkins University, School of Medicine, Baltimore, Maryland, USA
}

\section{Summary}

Measurement of 4-methylumbelliferyl p-guanidinobenzoate (MUGB)-hydrolyzing activity in the plasma of normal controls, cystic fibrosis (CF) heterozygotes, and $\mathrm{CF}$ homozygotes did not support previously reported (35) differences in MUGB-hydrolyzing activity. We identified human plasma albumin as the major source of MUGB-hydrolyzing activity by comparison of our plasma results to those obtained with physiologic concentrations of commercial albumin samples. Substantiating evidence was obtained from gel filtration experiments and correlation of albumin levels in CF plasma with MUGB titers. We found essentially no proteolytic activity towards dinitrophenylprotamine sulfate associated with commercial albumin samples. It appears that the reaction between human albumin and MUGB represents a weak esterase activity, perhaps involving the acylation of a specific site(s) on the protein.

Hypoalbuminemia has been documented (8) in some CF patients. Low albumin concentrations, indicated by MUGB titers $<190$ nmole methylumbelliferone/ml plasma, were found in $42 \%$ 
of CF homozygotes, $6 \%$ of heterozygotes, and $4 \%$ of controls. Gel filtration studies of a normal amniotic fluid supernatant indicated that albumin was the major MUGB-hydrolyzing substance in this fluid. We conclude that MUGB abnormalities are not associated with the basic gene defect in $C F$ and cannot be used as the basis of a test for intrauterine or heterozygote detection.

\section{Abbreviations}

CF, cystic fibrosis

DMSO, dimethyl sulfoxide

MU, methylumbelliferone

MUGB, 4-methylumbelliferyl p-guanidinobenzoate

RFU, relative fluorescence units

With an estimated incidence of 1:2000 births (36), CF is the most common lethal inherited disorder in Caucasian populations. The major clinical features are exocrine pancreatic insufficiency, chronic obstructive pulmonary disease, and an increased loss of elestrolytes in sweat. The basic defect is unknown and there is no reliable method for intrauterine detection or heterozygote identification.

Reports $(18,19,31-34)$ by Nadler and co-workers suggested that the intrauterine detection of $\mathrm{CF}$ was possible based on a decreased concentration of a substance(s) in amniotic fluid supernatant that hydrolyzed MUGB (13), an active site titrant of trypsin-like proteinases. The MUGB-hydrolyzing substance(s) was described as a protease $(31,34)$. Altered patterns of MUGBhydrolyzing fractions after gel filtration and missing bands after isoelectric focusing further differentiated CF from normal amniotic fluid $(18,19,34)$. Although the MUGB-hydrolyzing protein was partially characterized, neither its exact identity nor its relationship to any biochemical abnormality in CF was established. In addition, Nadler and colleagues $(24,35)$ reported differences in the plasma levels of MUGB-hydrolyzing substances in a small sample of CF homozygotes, heterozygotes, and controls.

The purpose of this study was to confirm the MUGB-based analysis using a large sample of plasmas and to identify the protein(s) that reacts with MUGB. Unexpectedly, the results of our studies (2) demonstrated that levels of MUGB-hydrolyzing activity are related to the plasma albumin concentration. Furthermore, we could not reproduce the reported (35) differences in MUGB titers among controls, $\mathrm{CF}$ homozygotes, and $\mathrm{CF}$ heterozygotes (2).

\section{MATERIALS AND METHODS}

Human albumin (essentially globulin-free), albumin color reagent, barbital buffer, benzamidine hydrochloride, 2,4-dinitrofluorobenzene, ellagic acid, Folin and Ciocalteu's Phenol Reagent, human $\gamma$-globulins, MU, 4-MUGB hydrochloride, protamine sulfate (clupeine), human protein standard solution, and quinine hemisulfate were obtained from Sigma Chemical Company. Dimethyl sulfoxide (Baker) was purified (11) and vacuum distilled before use and charcoal-filtered distilled and deionized water was used throughout. All other chemicals and solvents were reagent grade or better.

Blood was obtained from 38 patients with $\mathrm{CF}$ followed at the Milwaukee Children's Hospital (MCH) or Johns Hopkins Hospital (JHH), 50 obligate heterozygotes, and 53 healthy controls. The ages of the subjects were the following: CF homozygotes, $3-$ 39 years $($ mean $=19.2$ years); $\mathrm{CF}$ heterozygotes, $23-50$ years (mean $=37.0$ years); and healthy controls, $18-58$ years $($ mean $=$ 34.1 years)

Venous blood was collected in citrated or heparinized tubes and centrifuged for $15 \mathrm{~min}$ at $2500 \times g$ at $4^{\circ} \mathrm{C}$. Plasma was separated and stored at $-20^{\circ} \mathrm{C}$. Unless otherwise indicated, plasma was thawed and used directly ("unactivated"). Chloroform-ellagic acid pretreatment $(9,21)$ was performed to prepare "activated" plasma samples for several experiments as indicated.

A sample of amniotic fluid supernatant was obtained from a second trimester diagnostic amniocentesis. There was no family history of $\mathrm{CF}$ and the outcome of the pregnancy was a healthy child.

MUGB assays of plasma were carried out according to the method of Walsh-Platt and co-workers (35). Unactivated plasma samples were diluted 1:8 with distilled water and $20 \mu \mathrm{l}$ aliquots were incubated for $1 \mathrm{~h}$ with MUGB in the presence and absence of benzamidine (35). The amount of MU released from MUGB was determined with an Aminco-Kiers or Hitachi Perkin-Elmer MPF-2A spectrofluorimeter using $\tau_{\text {exc }}=365 \mathrm{~nm}$ and $\tau_{\text {emis }}=450$ $\mathrm{nm}$. A standard curve was prepared with MU solutions $(0.08$ $0.7 \mu \mathrm{M}$ ) in $0.1 \mathrm{M}$ barbital buffer, $\mathrm{pH}$ 8.3-4\% DMSO and compared to a $4.7 \mu \mathrm{M}$ quinine hemisulfate standard solution in the same buffer. The spectrofluorimeter was standardized daily so that the quinine standard gave 140 RFU using $\tau_{\mathrm{exc}}=330$ and $\tau_{\text {emis }}=380 \mathrm{~nm}$. A $0.5 \mu \mathrm{M}$ MU solution gave $240 \mathrm{RFU}$. Results of MUGB titers are reported as nmole $\mathrm{MU} / \mathrm{ml}$ original plasma/ $\mathrm{h}$; specific activity, MUGB titer/mg protein; MUGB hydrolysis, nmole $\mathrm{MU} / \mathrm{ml}$ original solution/h (no benzamidine correction); and specific hydrolyzing activity, MUGB hydrolysis/mg protein. All assays were carried out at least in duplicate and the 141 plasma samples in the study were coded and tested in a blind fashion.

Proteolytic activity was measured with the substrate dinitrophenylprotamine sulfate using the procedure of Brown et al. (4) as modified by Rao and Nadler (21).

Total protein was measured by the method of Lowry (15). Albumin concentrations were determined with a bromcresol green binding assay in which a chromogenic albumin-dye complex is detected by its absorbance at $630 \mathrm{~nm}(28)$. A standard curve was generated with dilutions of the Sigma human protein standard (0.1-5.0 $\mathrm{mg}$ albumin).

Gel filtration experiments were carried out by applying $1-\mathrm{ml}$ samples to a Sephadex G-150 (superfine) column $(2.5 \times 45 \mathrm{~cm})$ equilibrated with $0.1 \mathrm{M} \mathrm{KCl}-0.05 \mathrm{M}$ Tris buffer, $\mathrm{pH} 8.0$ and eluting with the same buffer at a flow rate of approximately 3 $\mathrm{ml} / \mathrm{h}$. Samples applied to the column were the following: normal control plasma, activated control plasma $(1.6 \mathrm{ml})$, Sigma human protein standard, CF plasma, and amniotic fluid supernatant prepared by lyophilizing $10 \mathrm{ml}$ of fluid and redissolving the residue in $1 \mathrm{ml}$ of $0.16 \mathrm{M}$ aqueous sodium chloride. Fractions $(1.5-3.0 \mathrm{ml})$ were collected and followed by absorbance measurements at $280 \mathrm{~nm}$. Albumin concentrations were measured by the bromcresol green assay of $100 \mu \mathrm{l}$ aliquots of each fraction. MUGB hydrolyzing activity (no benzamidine added) was measured with $20 \mu \mathrm{l}$ of undiluted fractions as described above.

Results are reported as mean \pm standard deviation. The significance of the difference of the means was assessed by unpaired Student's $t$ test, and the correlation coefficient was determined by linear regression analysis (17).

\section{RESULTS}

MUGB-plasma study. Results of plasma-MUGB hydrolyzing activity in $\mathrm{CF}$ homozygotes, heterozygotes and controls are shown in Table 1. Low MUGB titers $(<190 \mathrm{nmole} \mathrm{MU} / \mathrm{ml}$ plasma) were found in $42 \%$ of CF homozygotes, $6 \%$ of heterozygotes, and $4 \%$ of controls. There were statistically significant differences between controls $(234 \pm 32)$ and heterozygotes $(250$ $\pm 41)(P<0.025)$, and between CF homozygotes $(222 \pm 54)$ and heterozygotes $(250 \pm 41)(P<0.005)$ whereas the difference between controls $(234 \pm 32)$ and $C F$ homozygotes $(222 \pm 54)$ was not significant $(P>0.05)$. Although there were statistically significant differences in MUGB titers of CF homozygotes versus heterozygotes, all groups had wide ranges of MUGB titers, which overlapped considerably.

Preliminary identification of MUGB-hydrolyzing substance. The reaction of control plasma with MUGB in the absence of benzamidine released approximately $0.6-0.8 \mu$ mole $\mathrm{MU}$ per $\mathrm{ml}$ 
of original plasma. Accepting Nadler's contention (vide infra) that the MUGB-plasma reaction was "titrant-like," we estimated that the plasma MUGB-hydrolyzing substance was approximately $0.6-0.8 \mathrm{mM}$, a value consistent with normal plasma albumin levels $(0.58-0.77 \mathrm{mM})(28)$. The reaction of commercially available plasma proteins with MUGB was measured. The results (Table 2) indicate that albumin is the major plasma substance that reacts with MUGB.

Gel filtration experiments. To substantiate our finding that human albumin hydrolyzes MUGB, we carried out a series of Sephadex G-150 gel filtrations with samples of an untreated normal plasma, a $\mathrm{CHCl}_{3}$-ellagic acid pretreated normal plasma, a CF plasma, a commercial human protein standard, and a normal amniotic fluid supernatant.

A distinct late eluting peak was observed in the Sephadex G150 chromatograms of all samples (Fig. 1). Based on bromcresol green assays, most of the applied albumin was found in the slowest moving protein band. In all experiments, coincident MUGB hydrolyzing activity was associated with the albumin band. A small amount of bromcresol green staining and MUGBhydrolyzing protein was observed in the early globulin fractions. Unlike the plasma protein containing samples, the amniotic fluid supernatant did not show a broad peak of high molecular weight protein.

Table 1. Comparison of plasma-MUGB hydrolyzing activity

\begin{tabular}{|c|c|c|c|}
\hline Source & $\begin{array}{c}\text { Titer }^{1.2} \\
\text { (nmole } \mathrm{MU} / \mathrm{ml})\end{array}$ & Range & $\begin{array}{c}\text { Specific } \\
\text { Activity } \\
\text { (nmole } \mathrm{MU} / \mathrm{mg} \\
\text { protein) }\end{array}$ \\
\hline \multicolumn{4}{|l|}{ Controls } \\
\hline $\begin{array}{l}\mathrm{MCH}, \mathrm{JHH}(n= \\
53)\end{array}$ & $234 \pm 32$ & $159-279$ & $3.4 \pm 0.7$ \\
\hline Nadler $(n=7)^{4}$ & $254 \pm 46$ & & $3.6 \pm 0.7$ \\
\hline \multicolumn{4}{|l|}{ Heterozygotes } \\
\hline $\mathrm{JHH}(n=50)$ & $250 \pm 41$ & $152-290$ & $3.5 \pm 0.6$ \\
\hline Nadler $(n=11)^{4}$ & $141 \pm 23$ & & $2.0 \pm 0.3$ \\
\hline \multicolumn{4}{|l|}{ Cystic fibrosis } \\
\hline $\begin{array}{l}\mathrm{MCH}, \mathrm{JHH}(n= \\
38)\end{array}$ & $222 \pm 54$ & $129-398$ & $3.0 \pm 0.9$ \\
\hline Nadler $(n=12)^{4}$ & $97 \pm 33$ & & $1.4 \pm 0.5$ \\
\hline
\end{tabular}

${ }^{1}$ Our results with $1 \mathrm{~h}$ incubation, Nadler used 2 h. Nadler has shown (reference 35) and we confirmed that MUGB hydrolysis by control and CF plasma increases $\leqslant 10 \%$ from $1-2$ h total incubation time. Abbreviations: MU, methylumbilliferone and MUGB, 4-methylumbelliferyl $p$ guanidinobenzoate.

${ }^{2}$ Nadler data corrected for multiplication error, G. J. S. Rao, personal communication.

${ }^{3}$ Protein determined by Lowry Method: $70 \mathrm{mg} / \mathrm{ml}$ total protein used in determining Nadler's results.

${ }^{4}$ Reference 35 .

Table 2. Plasma protein-MUGB hydrolyzing activity'

\begin{tabular}{lc}
\multicolumn{1}{c}{ Sample } & $\begin{array}{c}\text { MUGB titer } \\
\text { [nmole MU/ml/h } \\
\text { incubation] }\end{array}$ \\
\hline $\begin{array}{l}\text { Control plasma } \\
\quad(69 \mathrm{mg} / \mathrm{ml} \text { total protein })\end{array}$ & $242 \pm 29$ \\
$\begin{array}{l}\text { Sigma human protein standard } \\
\quad(50 \mathrm{mg} / \mathrm{ml} \text { human albumin, } 30 \mathrm{mg} / \mathrm{ml} \gamma-\end{array}$ \\
$\quad$ globulins $)$ \\
$\begin{array}{l}\text { Sigma human albumin } \\
\quad(50 \mathrm{mg} / \mathrm{ml})\end{array}$ \\
$\begin{array}{l}\text { Sigma human } \gamma \text {-globulins } \\
(30 \mathrm{mg} / \mathrm{ml})\end{array}$ \\
\hline
\end{tabular}

\footnotetext{
'Abbreviations: $\mathrm{MU}$, methylumbilliferone and MUGB, 4-methylumbelliferyl p-guanidinobenzoate.
}

For all gel filtration experiments (Table 3), 76-85\% of the applied MUGB-hydrolyzing activity was recovered along with $80-94 \%$ of albumin. Furthermore, the specific MUGB-hydrolyzing activities of the recovered albumin fractions from all sources were similar ranging from 8.2-9.8 nmole $\mathrm{MU} \mathrm{ml} /(\mathrm{h} \cdot \mathrm{mg})$.

Relationship between $M U G B$ titers and albumin concentration. To determine whether MUGB titers were directly related to plasma albumin concentrations, we measured the albumin levels and MUGB titers of $11 \mathrm{CF}$ plasmas and several concentrations of a commercial human protein standard. All specimens were diluted $1: 20$ rather than $1: 8$ before incubation with the fluorogenic reagent because we had observed (1) that the titration did not give a linear response at albumin levels $\gtrsim 2.5 \mathrm{mg} / \mathrm{ml}$. A least squares linear regression analysis of the data (Fig. 2) indicated a good fit $\left(r^{2}=0.93\right)$ for a linear relationship between albumin content and MUGB titer in CF plasma. Also, the data points obtained with albumin from the commercial sample fit quite closely to the line for the CF plasmas (Fig. 2).

Absence of proteolytic activity of albumin. Proteolytic activity toward dinitrophenylprotamine sulfate had been observed (21) in plasma pretreated by $\mathrm{CHCl}_{3}$ extraction and ellagic acid incubation $(4,21)$. As the results in Table 4 indicate, we reproduced the level of proteinase activity reported (21) for normal plasma, but no significant level of proteinase activity was detected in the commercial albumin samples (Table 4).

Nature of the MUGB-albumin reaction. The slow hydrolysis of MUGB by plasma albumin could indicate that the protein is acting primarily as a macromolecular anion, $\mathrm{pI}=5.8-5.9$, (30) or as a weakly catalytic substance that is being acylated by MUGB. When 1.7 nmole of commercial human albumin were incubated with an approximately 35 molar-excess of MUGB, the rate of production of hydrolysis product (corrected for buffer catalyzed hydrolysis) leveled off in approximately $2 \mathrm{~h}$ after $\simeq 4.5$ nmole of MU had been released (Fig. 3). Nearly 3 nmole of MUGB were hydrolyzed per nmole of human albumin, although excess MUGB was still present. In a similar experiment (Fig. 3), when an additional $1.8 \mathrm{nmole}$ of human albumin were added after $80 \mathrm{~min}$, the rate of MUGB hydrolysis increased rapidly and then leveled off after approximately 6.5 additional nmole of MU had been released $(\simeq 3.6 \mathrm{nmole} \mathrm{MU} / \mathrm{nmole}$ human albumin).

\section{DISCUSSION}

The results of our blind study of 141 plasma samples failed to confirm previously reported differences in MUGB titers or specific activity among normal controls, $\mathrm{CF}$ heterozygotes, and $\mathrm{CF}$ homozygotes. We did, however, detect low MUGB titers $(<190$ $\mathrm{nmole} \mathrm{MU} / \mathrm{ml}$ plasma) in $42 \%$ of $\mathrm{CF}$ homozygotes, but in only $6 \%$ of CF heterozygotes and $4 \%$ of controls. Nadler and coworkers $(24,35)$ identified very low MUGB levels in seven CF patients and intermediate values in CF heterozygotes. We speculate that the difference in the findings between the two studies may be a function of the sample sizes. Although we did observe statistically significant differences between controls and $\mathrm{CF}$ homozygotes and between CF homozygotes and heterozygotes, each group showed a wide range of MUGB titers (Table 1). The extensive overlap of the MUGB values of the three groups precludes any diagnostic application of MUGB levels.

We identified albumin as the principle MUGB-hydrolyzing substance in plasma. Commercial samples of human albumin at normal physiologic concentrations had MUGB titers and specific activities similar to those seen in normal controls. Substantiating evidence was accumulated from Sephadex G-150 gel filtration studies, which demonstrated that MUGB-hydrolyzing activity and albumin co-eluted when samples of commercial human protein, normal plasma, and CF plasma were chromatographed. A small amount of bromcresol green staining and MUGBhydrolyzing protein was also observed in the globulin fractions (Fig. 1). Presumably, this material represents polymeric albumin (20) and/or albumin-globulin complexes (27). Untreated and 

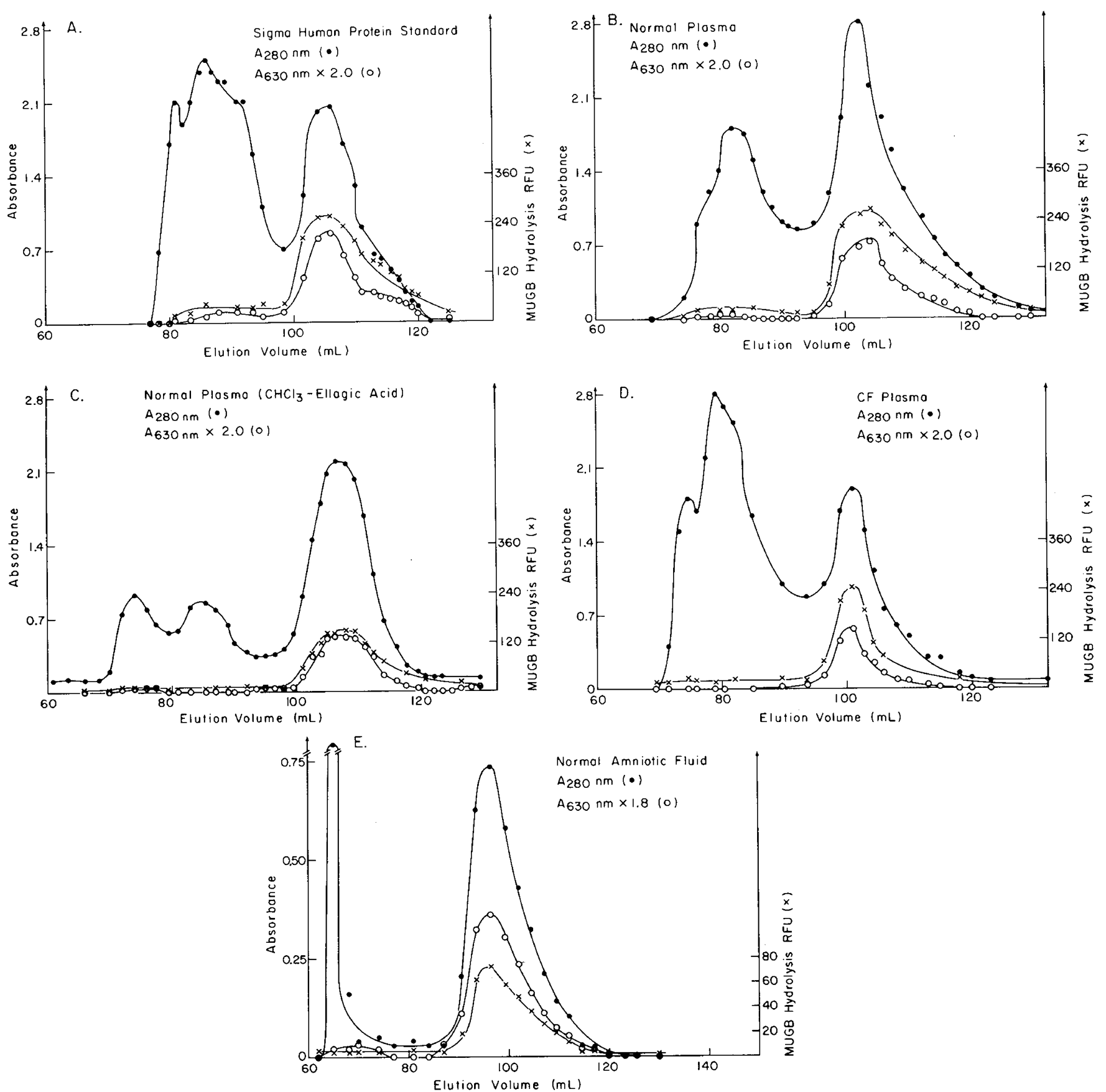

Fig. 1. Sephadex G-150 gel filtration patterns of plasma and amniotic fluid proteins. One-ml samples were applied to a column (2.5 x $45 \mathrm{~cm})$ and eluted with $0.1 \mathrm{M} \mathrm{KCl}-0.05 \mathrm{M}$ Tris buffer, $\mathrm{pH}$ 8.0. Fractions were monitored by their absorbance at $280 \mathrm{~nm}$, tested for albumin content by the bromcresol green assay $\left(\mathrm{A}_{630} \mathrm{~nm}\right)$ and for MUGB-hydrolyzing activity as described in "Materials and Methods." Samples were $(A)$, Sigma human protein standard; $(B)$, normal plasma; $(C), \mathrm{CHCl}_{3}$-ellagic acid pretreated normal plasma $(1.6 \mathrm{ml}) ;(D) \mathrm{CF}$ plasma (pooled from three patients); and $(E)$, normal amniotic fluid supernatant (concentrated from $10 \mathrm{ml}$ by lyophilization).

chloroform-ellagic acid pretreated normal plasma gave similar gel filtration results, except for the enhanced resolution observed in the high molecular weight protein region of the pretreated plasma. This is consistent with reports $(24,35)$ that chloroformellagic acid pretreatment does not alter MUGB titers.

Nadler and colleagues $(21,35)$ reported a molecular weight $\simeq 60,000$ for the putative MUGB-hydrolyzing protease, which showed several isozymes $(\mathrm{pl}=5.1-5.4)$ on isoelectrofocusing gels. Similarly, albumin has a molecular weight $\simeq 68,000(25)$, and gives several peaks on isoelectric focusing in the $\mathrm{pH} 5.2-5.5$ region (30). Also, the close correlation observed between albumin levels and MUGB-hydrolyzing activity in CF plasma is consistent with albumin being the major MUGB-hydrolyzing protein in plasma.
Approximately 3 mole MUGB are hydrolyzed per mole of commercial albumin. A similar ratio is obtained with plasma albumin when plasma is diluted to maintain levels of albumin $\leqslant 2.5 \mathrm{mg} / \mathrm{ml}$ before incubation with MUGB. Lower ratios of MUGB hydrolysis/albumin concentration are obtained with the standard MUGB titration conditions since plasma albumin levels are approximately $2-7 \mathrm{mg} / \mathrm{ml}$. The hydrolysis of MUGB by human plasma albumin is an indication of a weak esterase activity similar to the activity of albumin toward aspirin, $\rho$ nitrophenyl acetate, and a variety of other related compounds $(5,7,14)$. The leveling off of the rate of the reaction between MUGB and albumin in the presence of excess MUGB suggests that reactive sites on the protein are being blocked or perhaps acylated by the titrant. 
Table 3. Summary of gel filtration experiments

\begin{tabular}{lccc}
\hline \multirow{2}{*}{$\begin{array}{c}\text { Sample } \\
\text { (mg albumin) }\end{array}$} & \multicolumn{2}{c}{ \% Recovered } & \begin{tabular}{c} 
Specific \\
\cline { 2 - 3 } hydrolyzing \\
activity $^{2}$
\end{tabular} \\
\hline $\begin{array}{l}\text { Sigma human protein stan- } \\
\quad \text { dard (50.0) }\end{array}$ & 94 & 85 & $8.2 \pm 1.0$ \\
$\begin{array}{l}\text { Normal plasma (49.0) } \\
\text { Normal plasma (40.3) }\end{array}$ & 89 & 78 & $9.6 \pm 1.2$ \\
$\quad\left(\mathrm{CHCl}_{3}\right.$-ellagic acid treated) & 81 & 76 & $8.8 \pm 1.1$ \\
$\begin{array}{l}\text { CF plasma (32.0) } \\
\text { Normal amniotic fluid (18.2) }\end{array}$ & 80 & 75 & $9.8 \pm 1.2$ \\
\hline
\end{tabular}

'Abbreviations: MUGB, 4-methylumbelliferyl p-guanidinobenzoate.

${ }^{2}$ Based on MUGB-hydrolyzing activity recovered/mg albumin recovered for the lowest molecular weight (last) peak eluted. Error is estimated.

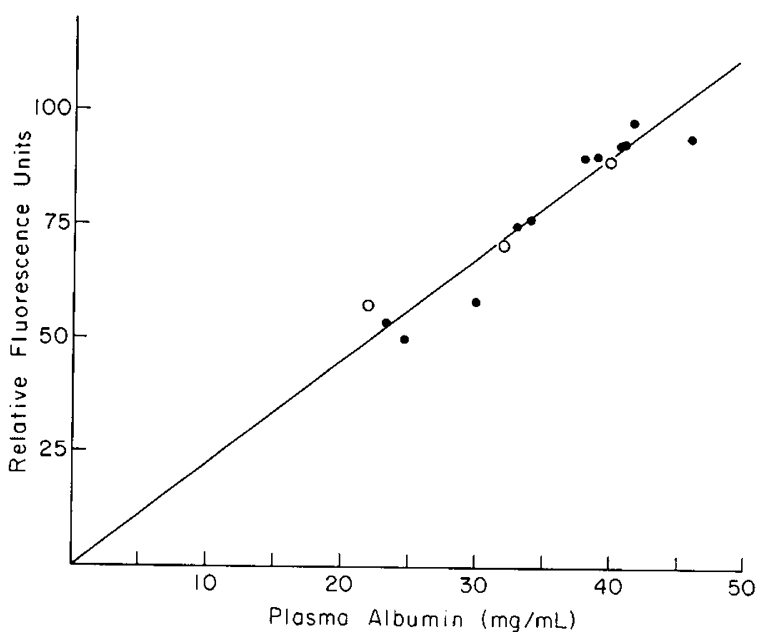

Fig. 2. Relationship of cystic fibrosis plasma albumin concentration to 4-methylumbelliferyl $\rho$-guanidinobenzoate (MUGB) titer (expressed in relative fluorescence units). The albumin content of $11 \mathrm{CF}$ plasmas (๑) was measured by the bromcresol green assay. Plasmas were diluted $1: 20$ with $0.16 \mathrm{M}$ aqueous sodium chloride and $20 \mu$ laliquots were used to determine MUGB titers as described in "Materials and Methods." Three dilutions of the Sigma human protein standard $(O)$ were also assayed for albumin content and MUGB titer. Plasma albumin levels $(\mathrm{mg} / \mathrm{ml})$ refer to the concentration in the fluid before dilution.

Table 4. Comparison of 4-methylumbelliferyl p-guanidinobenzoate (MUGB) titer and plasma proteolytic activity

\begin{tabular}{|c|c|c|}
\hline Sample ${ }^{1}$ & MUGB titer & $\begin{array}{l}\text { Proteolytic } \\
\text { activity }^{2} \\
\text { ( } \mu \text { eq Arg/h/ } \\
\text { ml plasma) }\end{array}$ \\
\hline Normal plasma (Nadler) ${ }^{3}$ & $254 \pm 46$ & $4.9 \pm 1.6$ \\
\hline Normal plasma & $319 \pm 38$ & $3.3 \pm 0.5$ \\
\hline $\begin{array}{l}\text { Sigma human protein standard } \\
(50 \mathrm{mg} / \mathrm{ml} \text { albumin, } 30 \mathrm{mg} / \mathrm{ml} \\
\text { globulins) }\end{array}$ & $258 \pm 30$ & 0.01 \\
\hline $\begin{array}{l}\text { Sigma human albumin } \\
\quad(50 \mathrm{mg} / \mathrm{ml})\end{array}$ & $254 \pm 30$ & 0.01 \\
\hline
\end{tabular}

Rao and Nadler $(21,22,23)$ measured a plasma arginine esterase activity toward $\alpha-N$-benzoyl-L-arginine ethyl ester and a proteolytic activity in plasma toward dinitrophenylprotamine sulfate (21). Similar reported differences in levels of arginine

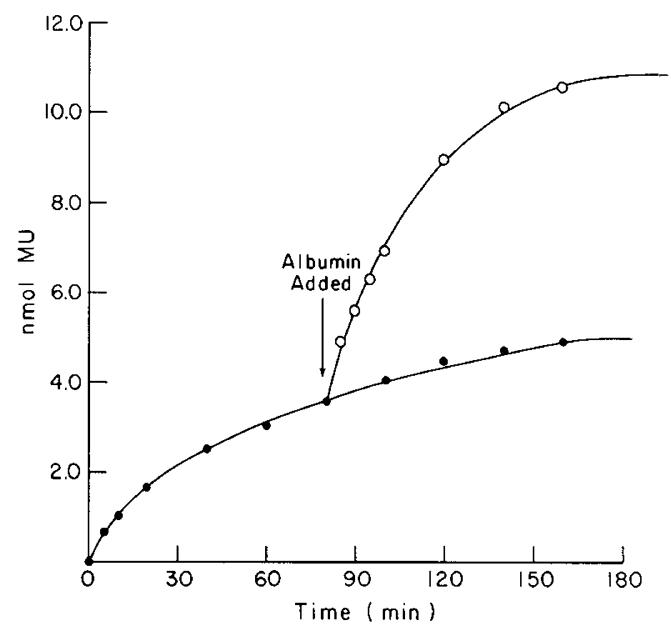

Fig. 3. Time dependence of 4-methylumbelliferyl $\rho$-guanidinobenzoate (MUGB) hydrolysis by human albumin. In two parallel experiments, $1.7 \mathrm{nmole}$ of human albumin in $0.1 \mathrm{ml} 0.1 \mathrm{M}$ barbital buffer, $\mathrm{pH}$ 8.3-4\% dimethyl sulfoxide was added to $0.9 \mathrm{ml}$ MUGB (final concentration $=67 \mu \mathrm{M})$ in the same buffer. After $80 \mathrm{~min}(\rightarrow)$, an additional 1.8 nmole albumin in $20 \mu \mathrm{l}$ of buffer $(\mathrm{O})$ was added to one mixture and 20 $\mu \mathrm{l}$ of buffer alone (-) to the other. At the times indicated, $50-\mu \mathrm{l}$ aliquots were withdrawn and methylumbelliferone (MU) levels were determined by fluorescence measurements. All MU determinations were corrected for buffer hydrolysis of MUGB in the absence of albumin.

esterase, proteinase, and MUGB-hydrolyzing activity in CF and normal plasma led them to suggest that MUGB was measuring a plasma proteinase(s) $(21,24,35)$. The commercial samples of albumin we tested did not hydrolyze the peptide substrate dinitrophenylprotamine sulfate, indicating that the protein has no significant proteinase activity. There is, however, a substance in plasma activated by chloroform and ellagic acid that has proteinase activity. This "activated" substance either does not react with MUGB at all or is present at a concentration far below the approximately $0.7 \mathrm{mM}$ normal level of albumin so that it does not measurably increase MUGB titers. Recently, Bury and Barrett (6) identified plasma kallikrein as the "arginine esterase" measured by Nadler's group $(22,23)$. We speculate that plasma kallikrein activity was measured with dinitrophenyl-protamine sulfate by Rao and Nadler (21). Their assumption that the arginine esterase/protease was also the MUGB-hydrolyzing substance is incorrect. Albumin hydrolyzes MUGB but has no measurable proteinase activity.

We hypothesize that assays of MUGB-hydrolyzing activity are measures of albumin concentrations. Our finding that albumin concentrations in some CF patients are nearly 2-fold lower than healthy controls is consistent with other reports (16). Hypoalbuminemia is seen with complications of $\mathrm{CF}$ including liver disease, protein-calorie malnutrition, and cor pulmonale $(8,16)$. Although we cannot rule out an abnormality in albumin (or a substance transported by it) as an important biochemical defect in $\mathrm{CF}$, it is more likely that the low plasma levels indicated by the MUGB assay are related to complications of the disease. Our findings indicate that there is no significant diagnostic value to plasma-MUGB measurements in $\mathrm{CF}$.

Nadler and colleagues $(18,19,31-34)$ have also reported the prenatal diagnosis of CF based on decreased MUGB-hydrolyzing activity in CF amniotic fluid supernatant, an absent band after isoelectric focusing, and an altered pattern of fractions reacting with MUGB after gel filtration. Presumably, their results with plasma formed the basis for the amniotic fluid studies. Our gel filtration and specific hydrolyzing activity results (Table 3 ) indicate that albumin is the predominant MUGB-hydrolyzing substance in normal amniotic fluid supernatant. In view of the absence of studies correlating abnormal albumin levels with the CF gene defect, it is difficult to understand how MUGB meas- 
urements of albumin concentrations in amniotic fluid might be the basis for a prenatal diagnostic test for CF. It is likely that the majority of albumin in amniotic fluid supernatant is of maternal original (29). Furthermore, a high incidence of false-positive and false-negative results have been obtained $(3,10,12,26)$ when the intrauterine diagnosis of $\mathrm{CF}$ has been attempted based on MUGB assays of coded amniotic fluid samples.

\section{ADDENDUM}

Two publications $(1,2)$ relevant to our findings have appeared since the submission of this manuscript. Schwartz (1) presented evidence that the main source of MUGB-hydrolyzing activity in plasma and amniotic fluid is albumin. Tümmler and co-workers (2) reported that the hydrolysis of MUGB was not significantly different in plasma samples from cystic fibrosis patients, obligate heterozygotes, and normal controls.

1. Schwartz, M.: A serine protease activity of human serum albumin towards 4-methylumbelliferyl-guanidinobenzoate (MUGB) and diisopropyl fluorophosphate (DFP): implications for the use of MUGB reactivity in amniotic fluid in prenatal diagnosis of cystic fibrosis. Clin. Chim. Acta, 124: 213 (1982).

2. Tümmler, B., Seger, E., and Riordan, J. R.: Systematic study of the hydrolysis of 4-methylumbelliferylguanidinobenzoate in plasma from patients with cystic fibrosis and controls. Clin. Chim. Acta, 125: 219 (1982).

\section{REFERENCES AND NOTES}

1. Branchini, B. R., Salituro, G. M., Freitag, J. G., Kapiloff, M. S., and Yokel, B. $\mathrm{K}$ : (unpublished results).

2. Branchini, B. R., Salituro, G. M., Rosenstein, B. J., and Bruns, W. T.: 4 Methylumbelliferylguanidinobenzoate reactive plasma "protease" in cystic fibrosis is albumin. Lancet, I: 618 (1982).

3. Brock, D. J. H. and Hayward, C.: Amniotic fluid esterases as markers for cystic fibrosis. Lancet, I: 619 (1982).

4. Brown, F., Freedman, N. L., and Troll, W.: Sensitive fluorescent determination of trypsin-like proteases. Biochem. Biophys. Res. Commun., 53: 75 (1973).

5. Bruno, J. J. and Ringold, H. J.: An enzyme-like activity of serum albumin. Fed. Proc., 28: 840 (1969).

6. Bury, A. F. and Barrett. A. J.: Plasma arginine esterase in cystic fibrosis: Kinetics of activation, identification as plasma kallikrein, reaction with $\alpha_{2-}$ macroglobulin and comparison with levels of normal plasma. Pediatr. Res., I6: 613 (1982).

7. Cassida, J. E. and Augustinsson, K-B.: Reaction of plasma albumin with 1naphthyl $\mathrm{N}$-methylcarbamate and certain other esters. Biochim. Biophys. Acta, 36: 411 (1959).

8. Chase, H. O., Long, M. A., and Lavin, M. H.: Cystic fibrosis and malnutrition. J. Pediatr., 95: 337 (1979).

9. Colman, R. W., Mattler, L., and Sherry, S.: Studies on the prekallikrein (kallikreinogen)-kallikrein enzyme system of human plasma. J. Clin. Invest., 48: 23 (1969)

10. Dann, L. G. and Blau, K.: Amniotic fluid esterases as markers for cystic fibrosis. Lancet $I: 619$ (1982).

11. Gordon, A. J. and Ford, R. A.: The Chemist's Companion. pp. 430-436 (Wiley, New York 1972).

12. Green, J. R., Lentze, M. J., Rossi, E., Sidiropoulos, D., and Schubiger, G.: Prenatal diagnosis of cystic fibrosis: false negative result with 4-methylumbelliferyl- $\rho$-guanidinobenzoate assay for proteases in amniotic fluid. Eur. J. Pediatr., 139: 35 (1982)

13. Jameson, G. W., Roberts, D. V., Adams, R. W., Kyle, W. S. A., and Elmore, D. $\Upsilon$.: Determination of the operational molarity of solutions of bovine $\alpha$ - chymotrypsin, trypsin, thrombin and Factor $\mathrm{Xa}$ by spectrofluorimetric titration. Biochem. J., 131: 107 (1973).

14. Kurono, Y. Yamada, H., and Ikeda, K.: Effects of drug binding on the esterase-like activity of human serum albumin. V. Reactive site towards substituted aspirins. Chem. Pharm. Bull., 30: 296 (1982).

15. Lowry, O. H., Rosenbrough, N. J., Farr, A. L., and Randall, R. J.: Protein measurement with the Folin reagent. J. Biol. Chem., 193: 265 (1951).

16. Lykkegaard, E., Jacobsen, L., and Flensborg, E. W.: Serum protein paper electrophoresis in cystic fibrosis correlated with clinical and radiological findings. Dan Med. Bull., 21: 232 (1974).

17. Moroney, M. J.: Facts from Figures. pp. 216-237 (Penguin Books, Inc., Baltimore 1969).

18. Nadler, H. L., Rembelski, P., Meserow, K., and Gerbie, A. B.: Prenatal detection of cystic fibrosis. Am. J. Obstet. Gynecol., 141: 885 (1981).

19. Nadler, H. L. and Walsh, M. M. J.: Intrauterine detection of cystic fibrosis. Pediatrics, 66: 690 (1980).

20. Pedersen, K. O.: Exclusion chromatography. Arch. Biochem. Biophys. Suppl., 1: 157 (1962).

21. Rao, G. J.S and Nadler, H. L.: Deficiency of arginine esterase in cystic fibrosis of the pancreas: Demonstration of the proteolytic nature of the activity. Pediatr. Res., 9: 739 (1975).

22. Rao, G. J. S. and Nadler, H. L.: Arginine esterase in cystic fibrosis of the pancreas. Pediatr. Res., 8: 684 (1974).

23. Rao, G. J. S., Posner, L. A., and Nadler, H. L.: Science, I77: 610 (1972).

24. Rao, G. J. S., Walsh-Platt, M., and Nadler, H. L.: Reaction of 4methylumbelliferylgunidinobenzoate with proteases in plasma of patients with cystic fibrosis. Enzyme, 23: 314 (1978).

25. Scatchard, G. Balchelder, A. C., and Brown, A.: The osmotic pressure of plasma and serum albumin. J. Clin. Invest., 23: 458 (1944).

26. Schwartz, M. and Brandt, N. J.: False-negative results with methylumbelliferylguanidinobenzoate reactive proteases in cystic fibrosis pregnancies. Lancet, $I I: 1226$ (1981).

27. Sharma, N. C., Mohammad, S. F., Chuang, H. Y. K., and Mason, R. G.: Albumin-IgG complexes in human serum and plasma that inhibit blood platelet adhesion. Proc. Natl. Acad. Sci. USA, 78: 7750 (1981).

28. Sigma technical bulletin No. 630, "The colorimetric determination of albumin." (Sigma Chemical Co., St. Louis, 1976).

29. Sutcliffe, R. B. and Brock, D. J. H.: Immunological studies on the nature and origin of the major proteins in amniotic fluid. J. Obstet. Gynaecol. Br. Common., 80: 721 (1973).

30. Valmet. E. The heterogeneity of human serum albumin. In H. Peeters (Ed.): Protides of Biological Fluids, Vol. 17, pp. 443-448 (Elsevier, Amsterdam. 1969).

31. Walsh, M. M. J. and Nadler, H. L.: MUGB-reactive proteases in amniotic fluid: possible marker for cystic fibrosis. Lancet, I: 622 (1979).

32. Walsh, M. M. J. and Nadler, H. L.: Prenatal detection of cystic fibrosis on amniotic fluid. Lancet, $I I: 96$ (1980).

33. Walsh, M. M. J. and Nadler, H. L.: Methylumbelliferylguanidinobenzoatereactive proteases in human amniotic fluid: promising marker for the intrauterine detection of cystic fibrosis. Am. J. Obstet. Gynecol., 137: 978 (1980).

34. Walsh, M. M. J., Rao, G. J. S., and Nadier, H. L.: Reaction of 4methylumbelliferylguanidinobenzoate with proteases in human amniotic fluid. Pediatr. Res., 14: 353 (1980)

35. Walsh-Platt, M., Rao, G. J. S., and Nadler, H. L.: Protease deficiency in plasma of patients with cystic fibrosis. Enzyme, 24: 224 (1979).

36. Wood, R. E., Boat, T. F., Doershuk, C. F.: State of the art: cystic fibrosis. Am. Rev. Resp. Dis., 133: 833 (1976).

37. Presented in part at the Cystic Fibrosis Club Meeting, Washington, May, 1982

38. The authors thank B. J. Yokel, T. S. Langbaum, J. G. Freitag, W. T. Bruns, and M. S. Kapiloff for their assistance.

39. Requests for reprints should be addressed to: Prof. Bruce R. Branchini, Biomedical Research Institute. University of Wisconsin-Parkside, Box 2000, Kenosha. WI 53141 (U.S.A.).

40. This research was supported by grants from the Cystic Fibrosis Foundation to B.R.B. and B.J.R.: and by funds from the Department of Chemistry, The Johns Hopkins University: and Science Division, University of WisconsinParkside.

41. Received for publication October 25, 1982.

42. Accepted for publication March 21, 1983. 